\title{
Options for financial support of local issues
}

\author{
Galina Morunova ${ }^{1, *}$, Svetlana Kuzmina ${ }^{2}$ and Taisiya Sorvina $^{2}$ \\ ${ }^{1}$ Saint-Petersburg State University of Economics, 21, Sadovaya st., St.-Petersburg, Russia \\ ${ }^{2}$ Saint-Petersburg State Institute of Film and Television, 13, Pravda str., Saint-Petersburg, Russia
}

\begin{abstract}
The search for additional options for financing issues of local importance and the organization of economic activity of municipalities is particularly relevant in the context of the economic crisis and budgetary constraints in Russia. According to the author, the reason for the low activity of municipal-private partnership projects is often explained by the complexity of interaction between business and municipalities. It is obvious that only cooperation and interaction at all levels can ensure the solution of a number of problems, and, as a consequence, municipal development. The tool of such inter-municipal, inter-level, within the municipality cooperation with citizens and business can be a target bond loan for the implementation of a specific project. The author substantiates this hypothesis on the example of foreign practice, as well as considering a specific example of a possible municipality with the use of a bond and possible restrictions on the use of this tool.
\end{abstract}

\section{Introduction}

Local self - government is the most important element of the state system in the democratic sphere, which is designed to ensure a combination of the interests of the state and the interests of the population of cities, towns and villages. To address issues of local importance, local authority is obliged to create conditions to meet the daily needs of citizens. This is what is the realization of civil law, which guarantees the right to a decent life in democratic States.

The search for additional options for financing issues of local importance and the organization of economic activity of municipalities is particularly relevant in the context of the economic crisis and budgetary constraints. It is clear that funds of citizens and businesses can become additional sources, the question is what should be the mechanism that allows accumulating these funds $[1-3]$.

\section{Theory or experimental methods}

The experience of developed foreign countries makes it possible to conclude that municipal bonds can become a tool that allows for cooperation of various interested economic entities [4 - 7].

\footnotetext{
*Corresponding author: morunova2009@mail.ru
} 
Municipal bonds are debt securities issued by States, cities, districts and other government agencies to Finance current obligations and such capital projects as building schools, highways or sewer systems. In the US, even such large - scale projects are most often not financed only by the state budget, but at the level of municipalities budgets. According to statistics, $70 \%$ of holders of municipal bonds in the US are individuals. Most often, the issuers of municipal securities are the subjects of the Federation [8]. This is due to the fact that certain competencies of the Issuer's management, which are usually available at a high managerial level, are necessary for the placement of bonds. Also, the volume of the loan should be large enough, so that the cost of its production and maintenance had economic feasibility. There are also certain conditions regarding the amount of borrowed funds. This amount cannot exceed the amount allocated to cover the budget deficit. For subjects of the Federation this volume shall not exceed $15 \%$ of the annual volume of the income excluding gratuitous receipts, and for subsidized regions $-10 \%$. For municipalities, this level is for $10 \%$ of annual revenues excluding non-repayable receipts [1]. The issue of municipal securities is regulated by the Civil code, the Budget code, Federal law № 39 dated 22.04.1996 "The securities market" and Federal law № 136 dated 29.07.1998 "The peculiarities of the issue and circulation of state and municipal securities".

Why do issuers issue municipal securities? First of all it is connected with the necessity to cover the budget deficit. That is why the legislative limits of emissions are "tied" to the difference between revenues and budget expenditures. It can be seen that the share of municipal bond loans in comparison with sub-Federal ones is extremely low (Fig. 1.1.).

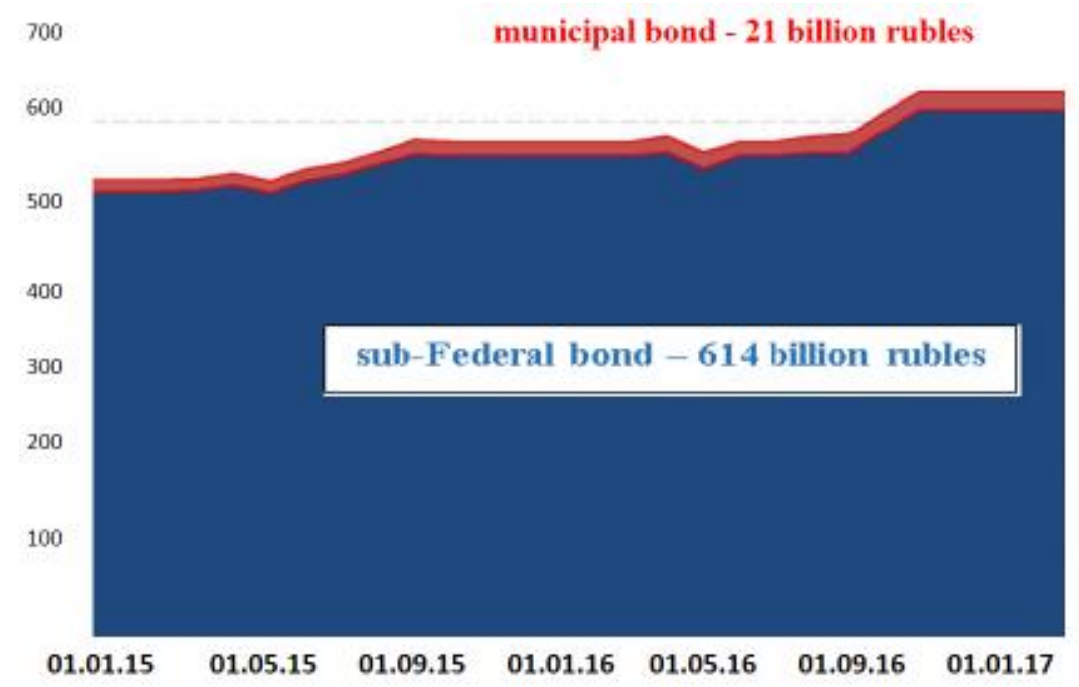

Fig. 1. The volume of the bond market of municipalities and regions of the Russian Federation.

This trend continues from year to year, which indicates that the main purpose of issuers is to close the negative balance of the budget.

\section{Results section}

A successful scheme to attract funding through the target bonds may be a situation where the city-forming enterprise (for example, with high or $100 \%$ share of state or municipal participation), experiencing difficult times and having the need to modernize the means of production or a complete change of direction activities, attracts the target bonded loan with state or municipal guarantees. On the one hand, this makes it possible not to spend a huge 
amount of budget on the implementation of this project, attracting money from the population, and on the other - it allows the population to invest free money in a clear project for them, demanded by them, and at the same time to get a yield slightly higher than on state instruments, but with state guarantees. After the implementation of the project, the income from the activities will be directed to the payments on the bonded loan.

\section{Discussion section}

In Russia, public-private partnerships are also frequently discussed. Thus, the Federal target program "Economic and social development of the Far East and the Baikal region for the period up to 2018" is being implemented in our country, the Strategy of social and economic development of the Far East and the Baikal region for the period up to 2025 was approved. At the same time, public-private partnership involves close cooperation between the state and business/individuals in the course of the implementation of large-scale economic projects.

An example of such a project implemented by the state in the framework of the above programs is the creation of the shipbuilding complex "Zvezda" on the basis of the plant for repair and disposal of nuclear submarines "Zvezda" in the city of Bolshoy Kamen Primorsky Krai. So, the last few years the number of orders and, accordingly, the demand of the entire plant for repair and disposal of nuclear submarines "Zvezda" has greatly decreased. Having come to realize this, the state decided to change the profile of the plant and build on it a shipbuilding cluster that produces large tankers.

The amount of the investment in this cluster was estimated at 140 billion rubles, a significant part of the money allocated Rosneft and Gazprombank, which are state-owned corporations [9]. These companies $75 \%$ are the owners of a newly built cluster, and $25 \%$ of it belongs to OSK - also of the state corporation. Thus, the complex is built entirely on state money.

Consider an alternative financing the construction of the project.

Legal entity of JSC «DCSS», carrying out the implementation of the project, locates the target bonded loan, which gets under the warranty provision of the Federal or regional government.

The coupon rate on this bond should be higher than on government bonds, as the investor should receive a risk premium, which, however, should be fairly adjusted due to the availability of state guarantees. If a key rate is found at the level of $7.75 \%$, the fair coupon for this bond may be $8-9 \%$ in annual terms.

Further, this loan is placed on the stock exchange, and all investors who consider it attractive participate in this placement. If the entire amount is not purchased by individuals and companies, it is possible to provide a mechanism for the redemption of the residual part of the debt placed by the same state corporations, which eventually finance this project now.

Another alternative for financing the project may be an option when the Issuer of the loan will be not a legal entity engaged in the construction of the cluster, but the municipality either Bolshoy Kamen (as the plant for this city is the city-forming enterprise) or Vladivostok (as it is the center of the region), or the Primorsky Region itself as a whole. In this case, of course, it is necessary to provide a scheme according to which the company will pay the Issuer of the loan.

The whole amount of investment to this project is estimated at 140 billion rubles. The amount of revenue part of their budgets for 2017 is approximately equal to 1.2 billion rubles for the city Bolshoy Kamen[10], 11.7 billion rubles for the city of Vladivostok[11] and 78 billion rubles for the Primorsky Region[12].

According to the legislation, the local budget deficit cannot exceed $10 \%$ of the budget revenues (without financial assistance). The limit of the municipal debt should not exceed the amount of budget revenues (without financial assistance). The cost of servicing the 
municipal debt can not exceed $15 \%$ of the budget. Limits the amount of borrowing should not be more than the amount allocated for the financing of the budget deficit. Thus, if we assume that fund the creation of a shipbuilding cluster are expenses for issue a municipal bond, for the city of Bolshoy Kamen (taking into consideration financial assistance in the amount of about 340 million rubles) the amount of borrowing could be about 85 million rubles, for Vladivostok, this figure could be no more than 1.17 billion rubles. This limits the amount of borrowings would not and $1 \%$ to fund the creation of the cluster.

Alternatively, the city of Bolshoy Kamen could carry out a loan for the construction of roads and other infrastructure for the cluster under construction (i.e. part of the investment project).

For the subject of the Russian Federation, the size of the budget deficit can not exceed $15 \%$ of budget revenues (without financial assistance). The debt limit should not exceed the budget revenues (without financial assistance). The debt service costs cannot exceed $15 \%$ of the budget. He himself limits the amount of borrowing should not be more than the amount allocated for the financing of the budget deficit. Thus, for Primorsky Region, taking into account the fact that its own budget revenues will amount to about 66.6 billion rubles, the limit of borrowing can be 10 billion rubles. This amount is about $7 \%$ of the amount required to finance the project.

Under the current budget rules, it is impossible to carry out municipal borrowing to finance the entire project.

An alternative would be the issuance of municipal bonds under the guarantees of the region with placement among the residents of the city and business.

The obstacle to the realization of this project may be that in Primorsky Region not only a small number of the population are participants in the securities market (a lot of explanatory work is needed), but there are practically no broker companies there either.

Thus, only a small part of the financing can be attracted within the region. A substantial part of the bonded loan will be purchased in one way or another by participants in the securities market, located territorially in the western part of our country.

And, nevertheless, the variant of co-financing of this project through the municipal target bond loan may well take place in our country. Of course, with due efforts and desire of the state bodies to do this.

Banks play a key role in placing municipal bonded loans. On the one hand, they are the organizers of such placement, i.e. they are providing a procedure for the issuance of these bonds. On the other hand, banks provide liquidity of these securities, by selling them to their customers and buying into their funds. Thus, they fulfill the most important function - they are intermediaries between the seller and the buyer of this bonded loan. As an example, which shows the attractiveness of municipal bonds, share investment bonds fund under the management of the investment company "ATON" can be cited. $8.3 \%$ of the fund's portfolio consists of bonds of the Republic of Khakassia. This position is the third in terms of volume in the fund. After analyzing the debt burden of the regions that are currently operating issuers, it was understood that the average ratio of the region's debt to its revenues is $50.8 \%$. In the Republic of Khakassia, this figure is almost twice as much - $96.3 \%$.

This indicates an extremely high debt burden of this region. Nevertheless, on the eve of the elections in March 2018, the default of the regions is out of the question. In the current conditions, the investment idea on bonds of the Republic of Khakassia can be quite profitable at a controlled level of risk.

In general, if we talk about the situation in the sector of municipal bonds, it is necessary to focus on the level of the debt burden of the regions. Among the issuers of municipal bonds, this figure is $50 \%$ by mid-October 2017 . On the average, $28.22 \%$ of the total debt of the subjects falls on debts on bonded loans. 
The total volume of municipal bonds placed and not repaid at the moment, is 454.88 billion rubles. In total, at present, the debt of the regions that are issuers is 1495.7 billion rubles. On average, $28.22 \%$ of the total debt of the subjects falls on debts on bonded loans.

As can be seen from Table. 1, since 2012 the number of municipal bond issues has declined, but in 2016 this trend was interrupted, which in many ways can be attributed to problems in the Russian economy itself.

If in 2015 high volatility on the securities market was stopping issuers, then in 2016 the budget deficit still had to be filled by raising funds from the market through bonded loans. 2017 is not over yet, but the number of placements has approached the total number of placements in 2015. And the trend in the number of placements at the end of each year suggests that 2017 on this indicator can surpass 2016, continuing the positive trend.

Table 1. Number of new placements of municipal bonded loans by year [13].

\begin{tabular}{|c|c|c|c|c|c|c|}
\hline Year & 2012 & 2013 & 2014 & 2015 & 2016 & 2017 \\
\hline $\begin{array}{c}\text { Number } \\
\text { of placements }\end{array}$ & 31 & 28 & 26 & 19 & 22 & 16 \\
\hline
\end{tabular}

If you look at the geography of placements, the greater number of issuing regions falls on the Central Federal District. This is due primarily to the fact that all finances gravitate toward the capital of the country, as well as the fact that there are necessary competencies in this region. Fewer number of attractions falls on the North Caucasus Federal District, where at the moment there is only one issuer. This is due to the fact that in this region there are a high proportion of subsidized entities. Also, a small number of issuers account for the Southern Federal District and the Far Eastern Federal District, where they are 2 for each of these districts. The Volga, North-Western and Siberian Federal Districts are also large in terms of number of issuers.

If we talk about individual subjects, it is important to note those who have a high share of debts in relation to the subject's income. The top ten of this indicator are the following subjects (Table 2).

Table 2. The ratio of debt of the subject of the Russian Federation to the revenue side of its budget, $\%[14,15]$.

\begin{tabular}{|l|l|}
\hline Mordovia & 148,6 \\
\hline Kostroma Region & 111,1 \\
\hline Khakassia & 96,3 \\
\hline Karelia & 92,0 \\
\hline Smolensk Region & 90,8 \\
\hline Udmurtia & 90,6 \\
\hline Belgorod Region & 78,3 \\
\hline Krasnodar region & 73,2 \\
\hline Volgograd Region & 71,0 \\
\hline Yaroslavl Region & 66,0 \\
\hline
\end{tabular}

The first six of them are in a "special" risk group. The share of debt to income is more than $90 \%$. The most critical level of debt is in Mordovia and the Kostroma region. There is a high share of the likelihood that the debts of these entities will come first under restructuring.

If we talk about the indicator that characterizes the share of bonded loans in the structure of all the debts of the subject, the highest percentage falls on Khanty-Mansi Autonomous Area - Yugra, The Yamalo-Nenets Autonomous District and Moscow. For them, this indicator is $86.64 \%, 81.7 \%$ and $71.86 \%$ respectively. Despite the fact that the overwhelming 
majority of issuers of municipal bonded loans are the subjects of the Russian Federation, there is also a small number of issuers belonging to municipal entities. At the moment, there are 6 such issuers, whose bonds are currently in circulation. These include: the city of Novosibirsk, Omsk, Tomsk, Volgograd, Housing and Communal Services of the Republic of Sakha and the city of Volzhsky, located in the Volgograd region. The housing bonds of the Sakha Republic are related to the targeted bonded loans, the rest - to the municipal loans of general coverage. The total volume of bonds of the above-mentioned municipal entities is 19.3 billion rubles. The total volume of municipal bonds, placed and not repaid at the moment, is 742.9 billion rubles. That is, the total volume of municipal bonds for municipal entities bonds accounts for $2.6 \%$. The average size of one placement among all municipal bonds is 5.6 billion rubles. For municipal entities bonds, this figure is equal to 1.5 billion rubles, which is almost 4 times lower than the indicator for all municipal bonds.

\section{Conclusions}

The proposed project financing scheme will allow not only receiving private funding up to $25 \%$ of the cost of the project for this state important project, but will also enable domestic creditors to invest their money in an understandable to them project with state participation.

\section{References}

1. O.V. Nevskaya, Economics: yesterday, today and tomorrow 6(10A), 206-219 (2016)

2. G.V. Morunova, Theory, law and practice of the organization of municipal Finance in the transition economy (Publishing house FINEC, SPb, 2016)

3. A.V. Ramazanov, K.A. Grigorian, Procedia Economics and Finance 24, 537-542 (2015) ISSN 2212-5671, https://doi.org/10.1016/S2212-5671(15)00627-9

4. K. Gao, W. Lin, China Journal of Accounting Research 11(1), 51-70 (2018) ISSN $1755-$ 3091, https://doi.org/10.1016/j.cjar.2017.12.001

5. E. Kusakabe, Progress in Planning 80, 1-65 (2013) ISSN 0305-9006, https://doi.org/10.1016/j.progress.2012.06.001

6. G. Braun, S. Hazelroth, The Electricity Journal 28(5), 6-21 (2015) ISSN 1040-6190, https://doi.org/10.1016/j.tej.2015.05.008

7. M. Mwirigi M'Ikiugu, W. QianNa, I. Kinoshita, Procedia - Social and Behavioral Sciences 68, 815-825 (2012) https://doi.org/10.1016/j.sbspro.2012.12.269

8. URL :https://www.investor.gov/introduction-investing/basics/investmentroducts/municipal-bonds

9. URL : http://www.morvesti.ru/tems/detail.php?ID=55560 (2016)

10. URL : https://news.rambler.ru/other/38531280-smi-bolshoy-kamen-ostalsya-bezbolshih-deneg/

11. Official site of the Duma of Vladivostok, http://www.dumavlad.ru/news/pressreleases/2016-11-25-prinyat-byudzhet-vladivostoka-na-2017-2019-gody-utverzhdenyizmeneniya-v-ustav-v.htm

12. URL : http://www.primorsky.ru/news/120850/

13. URL :http://www.rusbonds.ru/

14. URL : http://www.roskazna.ru/

15. URL : http://www.minfin.ru 